\title{
SOBRE AS MARQUISES DE MILTON FRANCISCO: UM OU OUTRO COMENTÁRIO
}

\section{ON THE MARQUISES OF MILTON FRANCISCO: ONE OR ANOTHER COMMENT}

Cesar Augusto de Oliveira Casella ${ }^{1}$

FRANCISCO, Milton. Marquises. Rio Branco: Edufac, 2019.

Após a leitura de Marquises, de Milton Francisco, poeta e professor na UFAC (Universidade Federal do Acre), eu gostaria de fazer um comentário, para além daqueles feitos pelos resenhistas mais próximos (pois que eles estão secundando os poemas no livro...), Rodrigo Lopes de Barros e Simone de Souza Lima, os quais mostram bem as linhas de força do conjunto: A. os poemas de Marquises são achados na rua, extraem poesia de onde não se espera e devem (podem?) ser vistos como pertencentes à poesia marginal; B. a poesia apresenta-se, neste livro, como uma profunda desilusão permanente frente a modernidade canhestra do Brasil; C. a mobilidade e o trânsito contínuo são chaves vitais na leitura e compreensão do conjunto de poemas; D. há um forte viés de desautomatização (¡salve Chklóvski!) em Marquises.

Eu gostaria de fazer um comentário que partisse da assunção de que há outras possibilidades de construção de sentido para as marquises (o que, em si mesmo, já é um comentário...). Claro, é possível se posicionar sob as marquises, procurando abrigo das próprias cidades, terríveis cidades brasileiras. Mas é possível se posicionar sobre as marquises, procurando um outro ponto de observação das cidades (dá até para fazer um churrasquinho - ¡estilo laje! - em cima das marquises...).

Agora o comentário, anunciado inicialmente. Ao discutir a relação da filosofia com a linguagem, ao final de O que é isto - A filosofia?, Heidegger é levado a considerar a relação entre pensar e poetar. Assim, o filósofo alemão escreve que:

\footnotetext{
Entre ambos, pensar e poetar, impera um oculto parentesco porque ambos, a serviço da linguagem, intervêm por ela e por ela se sacrificam. Entre ambos, entretanto, abre-se ao mesmo tempo um abismo, pois 'moram nas montanhas mais separadas' (HEIDEGGER, 2018, p. 46).
}

A filosofia, como tenta estipular Heidegger em seu texto, é "uma correspondência, que manifesta na linguagem o apelo do ser do ente" (HEIDEGGER, 2018, p. 47). Para que a filosofia seja esta correspondência, para que ela investigue o que o ente é enquanto está sendo, é preciso que haja o "falar como diálogo" (HEIDEGGER, 2018, p. 31). É preciso, ainda, que haja o espanto, pois é ele que "carrega a filosofia e impera em seu interior" (HEIDEGGER, 2018, p. 38). Além disto, é preciso que a linguagem não seja vista como um instrumento de expressão, como se ela estivesse a serviço do pensamento (HEIDEGGER, 2018, p. 45).

A minha leitura de Marquises foi uma leitura trilhada neste obscuro parentesco entre poesia e filosofia. Sem pretender atravessar o abismo imposto por Heiddeger (jlejos de mí!...), creio que ao ler os poemas de Milton Francisco é preciso mergulhar no diálogo que faz com que o falar esteja

1 Doutorando em Letras pela Universidade do Estado do Rio de Janeiro, professor da Universidade Estadual de Goiás. 
prenhe de um outro que não nós mesmos (¡salve Bakhtin!). Pareceu-me, além disto, que os poemas de Marquises são plenos de espanto: do espanto do vagamundo, do espanto do migrante, do espanto do poeta brasileiro que viaja o Brasil.

$\mathrm{Na}$ continuidade (o que talvez possa ser visto como um outro comentário...), a linguagem de Marquises está longe de ser instrumento de expressão do pensamento. O poetar de Milton Francisco intervém pela linguagem, emerge na linguagem. Há, nos poemas do livro, um desborde linguajeiro que assevera o desborde poético: o ' $y$ ' hispânico, aditivo e fronteiriço, espalhado pelo livro; as reiterações contínuas em Urbanismo; o acento portunholesco de Boca Maldita; o paralelismo derivativo em Multiculturalismo; o título integrativo e provocativo em Sociorrudimentariedade; a locução irônica $<$ black plebe $>$ de Olhar confuso; etecétera e tar...

Para ficar com um exemplo desta linguagem de Marquises, veja-se o poema Discursos y mudança social (FRANCISCO, 2019, p. 26):

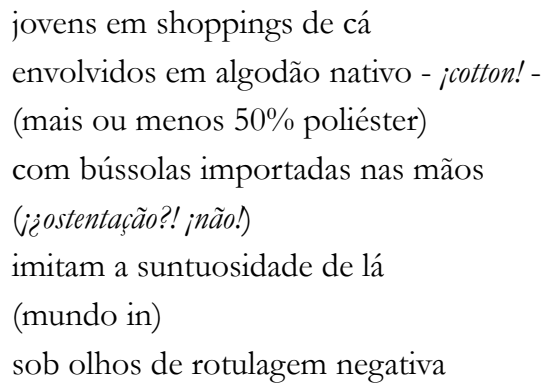

Um exemplo (como um comentário...) leva a outro exemplo:

\section{O repórter}

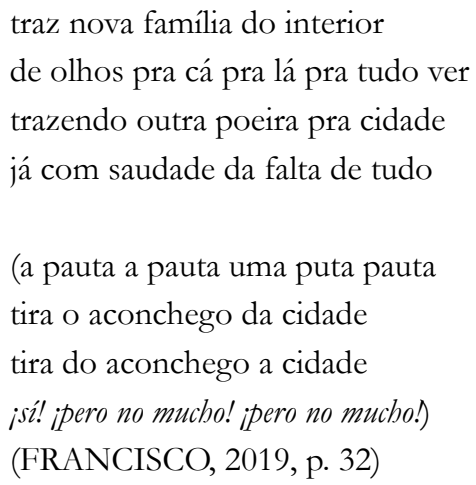

Em resumo (talvez...), e como aparece em Fragilidade urbana: y vozes, "poetiza hipoteticamente o poeta de observação participante" (FRANCISCO, 2019, p. 42). Assim, sem ser filosofia nos termos de Heiddeger, parece-me que o poetar de Milton Francisco perscruta o ente enquanto ser, parece-me que temos uma viagem ao ser do ente. E, já que é inevitável este jogo fonológico com as palavras, lá vai: parece-me que o poetar de Mílton Francisco é uma viagem ao ser doente da modernidade canhestra do Brasil e da América Latina.

\section{REFERÊNCIAS}

FRANCISCO, M. Marquises. Rio Branco: Edufac, 2019.

HEIDEGGER, M. O que é isto - A filosofia? Tradução de Ernildo Stein. Petrópolis (RJ): Vozes, 2018. 